IMPACTS OF AN IRON AND STEEL PLANT ON RESIDENTIAL PROPERTY VALUES

CELIA BILBAO-TERO

FUNDACIÓN DE LAS CAJAS DE AHORROS

DOCUMENTO DE TRABAJO

NN $339 / 2007$ 
De conformidad con la base quinta de la convocatoria del Programa de Estímulo a la Investigación, este trabajo ha sido sometido a evaluación externa anónima de especialistas cualificados a fin de contrastar su nivel técnico.

ISBN: 84-89116-07-5

La serie DOCUMENTOS DE TRABAJO incluye avances y resultados de investigaciones dentro de los programas de la Fundación de las Cajas de Ahorros.

Las opiniones son responsabilidad de los autores. 


\title{
Impacts of an iron and steel plant on residential property \\ values
}

\section{Celia BilbaO-Terol}

University of Oviedo. Department of Economics. Av. Del Cristo, no number. Postcode 33006. Oviedo, Asturias, Spain. Tel: +34985103722 . Fax: +34985104871 . E-mail: cbilbao@uniovi.es.

The author would like to thank funding provide by the research Proyect MEC-04SEJ2004-08253.

The author is grateful to the anonymous referee for their helpful suggestions and comments.

\begin{abstract}
.
The purpose of the research is to evaluate the effects on environmental quality caused by an integrated iron and steel plant located in the outskirts of Gijón, a city in the north of Spain. To carry this out, the method of Hedonic Prices is applied to the environmental field. The method relates the prices of dwelling units with their characteristics, including the environmental ones. This method allows to identify the "price" that consumers pay for the quality of the environment where their house is located. The results indicate that the effects of the plant on the value of the properties are significant. Decreases in the plant's production, the installation of contaminationreducing technology or the dismantling of the plant would lead to an increase in the value of the dwellings. The nearest ones to the factory would be the most favoured. Not accounting for environmental benefits could give rise to erroneous decisions when negotiating a possible restructuring of the industry.
\end{abstract}

Keywords: hedonic prices, housing, polluting industry, iron and steel plant, environmental quality.

JEL: D62, H21. 


\section{Introduction}

The goal of this study is to evaluate the effects on environmental quality caused by an integrated iron and steel plant located in the outskirts of Gijón, a city in the north of Spain. The main obstacle to achieving this objective is that while environmental quality is undoubtedly valuable, there are no market prices for it. However, different methods exist in the economic literature which try to correct this deficiency, such as hedonic pricing, travel costs, damage avoidance cost or contingent valuation ${ }^{1}$.

In this study the method of hedonic prices (Rosen, 1974) is applied. This method is based on the relation which exists between some heterogenous private goods and public goods. In our case, the heterogenous private good, comprising a multitude of characteristics or attributes, is the house, and the public good is the quality of the environment. One of the characteristics of each house is its environmental surroundings. Thus, when consumers choose their house, they also implicitly choose the environmental quality that they desire and pay a price for this.

The hedonic pricing technique takes account of the implicit price of environmental characteristics. The main advantages of the hedonic method with respect to other methods of valuation are the following (Gómez, 1996):

- Firstly, it is an indirect method, that is to say, it is based on what people reveal through their behaviour and not on what people declare in an interview, a survey or some type of laboratory experiment. This avoids possible biases in the survey or in the experiment.

\footnotetext{
${ }^{1}$ Surveys of these methods include Freeman III (2003) and Johansson (1993).
} 
- On the other hand, unlike other indirect methods, such as the travel costs, which try to place a value on a particular asset such as, for example, a natural park, the hedonic method tries to put a value on attributes or characteristics of the assets.

- Thirdly, it is the only method that allows the valuation of local public goods, defined as those goods whose benefit is related to the occupation of a particular geographic space.

Many studies have been conducted using the hedonic pricing method to evaluate environmental externalities, beginning in the 1960s with the work of Ridker (1967) on air pollution. This gave rise to a multitude of studies, among the most important of which were Brookshire et al. (1982), Graves et al. (1988), Ohsfeld and Smith (1990), Smith and Deyak (1975) and Smith and Huang (1995) on air quality, Benson et al. (1998), Bourassa et al. (2004), and McLeod (1984) on the impacts of views, Espey and Lopez (2000), McMillan (1979), McMillan et al. (1980) and Nelson (1978) on noise, Hughes and Sirmans (1992) on traffic noise, Gayer et al. (2000) on enviromental risk, Luttik (2000) on landscape and water quality, Anderson and Cordell (1988), Bengoechea-Morancho (2003), More et al. (1988), Powe et al. (1995), Tajima (2003), Tyrväinen (1997), and Jim and Chen (2005) on urban green spaces.

The effects of polluting industries have also been the subject of study. Notable among these are the studies by Folland and Hough (2000) and Gamble and Downing (1982) on proximity to a nuclear power station, those by Brasington and Hite (2005), Dale et al. (1999), Hite et al. (2001), Ihlanfeldt and Taylor (2004), Ketkar (1992), Kiel and Zabel (2001), Kohlhase (1991) and Michaels and Smith (1990) on discharges from polluted sites, the study of nuclear waste by Gawande and Jenkins-Smith (2001) and that of Letombe and Zuindeau (2005) on a lead production plant. However, there are no 
significant studies about the effects on environmental quality caused by iron and steel industries.

A representative sample of prices of new houses together with their characteristics for the city of Gijón in 2002 establishes the relation between house prices and their environmental surroundings. The results indicate that the environmental variables used (distance to the iron and steel plant and atmospheric contamination) exert a significant influence on house values. Improvements in these variables such as, for example, reductions in the production of the plant, reductions of emissions of polluting substances or increases in the distance to the plant would lead to a revaluation of the properties.

In the following section we describe the history of the factory and its surroundings. We then explain the theorical foundations of the hedonic pricing method, the empirical model used, and the results obtained. Finally, the main conclusions of the study are described.

\section{The industry and its surroundings}

Gijón is a city located on the shore of the Bay of Biscay in the northern Spanish region of Asturias and has a population of 275830 inhabitants according to the latest census. It has a strong metallurgical tradition that goes back to the 19th century but the city's modern iron and steel industry began in 1957 with the construction of an integrated iron and steel plant by the private company UNINSA (Iron and Steel Industries Union). The new factory was located $7 \mathrm{kms}$ away from Gijón's centre of population and $3 \mathrm{kms}$ away from the seaport. It began to produce steel in 1971, with production reaching 1800000 tons in 1973. 
In 1973 the factory was taken over by the public company ENSIDESA (National Iron and Steel Company). During the 1980s ENSIDESA underwent a series of rationalizations, with reductions of production and cutbacks in the workforce in all their factories including the one in Gijón. It began to be privatized in the middle of the 1990s, a process which ended in 2002. At the present time it belongs to the Arcelor Mittal group.

During the negotiations in the successive rationalizations, neither management nor unions considered the environmental benefits obtained by the reduction in production $^{2}$. This was in spite of the fact that the iron and steel industry is one of the most damaging to the environment, not only due to the high amount of polluting substances that it generates but also to the problems of water contamination generated by disposal of residues. Integrated iron and steel plants produce large amounts of polluting agents, with the main ones being particles (dust, smoke, fog, and fly ash), gases $\left(\mathrm{SO}_{2}, \mathrm{CO}, \mathrm{NO}_{2}\right.$, fluorides) and red smoke (iron oxides). With regard to water contamination, the main problem is the spillage of oils, dissolved metals, emulsions, soda caustic and acids to the water. These polluting agents have very damaging effects on human beings, being especially related to heart and respiratory problems. They have damaging effects on buildings and historical monuments, as well as on the green belts surrounding cities.

Not including the effects that a possible reduction in production has on the environment during negotiations can lead to erroneous decisions being taken from the economic point of view. Thus, the hedonic pricing method which we use in this study allows us to evaluate, in monetary terms, the environmental effects produced by a reduction in production or a dismantling of the polluting industry.

\footnotetext{
${ }^{2}$ Unfortunately there is not information about the amounts of polluting substances produced by the industry.
} 


\section{Methodology}

The analysis provided is based on the proposals of Lancaster (1966). In this framework, utility is not directly derived from goods, but from their intrinsic characteristics or attributes. This specific feature is considered in our analysis. The most common application of this approach is the so-called Hedonic Prices Method ${ }^{3}$ (Rosen, 1974). The Hedonic Price Method is an approach for estimating the implicit prices of the characteristics that differentiate closely related products belonging to the same product class.

The hedonic approach, regards a good as a set of attributes or characteristics and considers the good's value as a function of its attributes. The value of each characteristic is called its implicit (or hedonic) price, because it cannot be observed in a real market. Hedonic prices can be estimated, however, by analyzing the market prices of a good that has different attributes. The hedonic approach is defined as a method of revealing these implicit prices. The mapping which determines the market price of a good through these attributes is called the hedonic price function. As an economic method, this approach has very appealing characteristics because it is based upon revealed preferences of consumers and producers in actual markets. This section outlines Rosen's model and applies it to housing ${ }^{4}$.

The approach assumes that differences in property prices are due to different housing characteristics. Accordingly, property prices should reflect the extra money that people are willing to pay for greater size, greater quality of the house or for better

\footnotetext{
${ }^{3}$ The origin of the hedonic prices method is found in the investigations by Court (1939) and Griliches (1971) for the automobile sector, but studies usually begin by referring to the work of Rosen (1974) since this gives microeconomic foundations to the method.

${ }^{4}$ Before the seminal article by Rosen (1974), the hedonic technique had already been applied to the house market in numerous studies. Some examples of these applications can be found in the survey made by Ball (1973).
} 
environmental quality, e.g. a house near a public park. In this way, people can choose the level of consumption of local public goods through their choice of a jurisdiction to reside in; and the housing market functions also as a market for the purchase of local public goods.

More formally, let $\mathbf{z}=\left(\mathrm{z}_{1}, \mathrm{z}_{2}, \ldots \ldots, \mathrm{z}_{n}\right)$ be a vector of housing characteristics (size, quality, location, environment, age, etc.). The components of $\mathbf{z}$ are objectively measured in the sense that all consumers' perceptions of the amount of characteristics embodied in each housing are identical, though consumers of course may differ in their subjective valuations of alternative packages. It is assumed that a sufficiently large number of houses are available so that choice among various combinations of $\mathbf{z}$ is continuous for all practical purposes. The price of a house is given by hedonic price function:

$$
\mathrm{p}(\mathbf{z})=\mathrm{p}\left(\mathrm{z}_{1}, \mathrm{z}_{2}, \ldots \ldots, \mathrm{Z}_{n}\right)
$$

where $z_{1}, z_{2}, \ldots \ldots, z$ are the characteristics of the house.

The partial derivates of price with respect to the previous variables are implicit or hedonic prices:

$$
\frac{\partial \mathrm{p}(\mathbf{z})}{\partial \mathbf{z}_{i}}=\mathrm{p}_{\mathrm{i}}(\mathrm{z})
$$

This price provides information on the marginal willingness-to-pay price for an additional unit of each characteristic. As a result, the implicit price of individual characteristics can be deduced.

The hedonic method has a two-step approach that consists of the estimation of a system of demand and/or supply equations. Because of the demanding data 
requirements and the econometric problems associated with the second step ${ }^{5}$, most empirical studies have used only the first step of the hedonic regression model (Bengoechea-Morancho, 2003; Jim and Chen, 2005; Luttik, 2000; McMillan et al., 1980; Michaels and Smith, 1990; Tyrväinen, 1997; Willis and Garrod, 1993).

In this study we estimate the price hedonic function only. Our objective is to analyze the impact of the polluting industry on the values of the dwelling without making any type of welfare analysis.

\section{Estimation and Results}

The hypothesis of this study is that dwelling values are reduced by the contamination produced by the plant. That is, houses nearer the industry and/or that undergo a greater atmospheric contamination have a lower price, ceteris paribus, than those that are further from the industry or whose environment is less contaminated.

The relation between the price of the house and the quality of its environmental is established using a hedonic price function, which requires data on the prices of houses and the characteristics of these houses. Our data has been supplied by the real estate agency Foro Consultores Inmobiliarios S.L. (Real Estate Consultants Agency). The agency conducted market research on new apartment buildings in the city of Gijón during the months of May and June of 2002. A representative random sample of 166 apartments was selected from a total of 3501 new apartments ${ }^{6}$.

The data set comprises the following information: price before taxes; number of rooms; floor area; location; whether or not the residence has a garage; whether or not it

\footnotetext{
5 About the problems and solutions to the second stage analysis, there are studies by Follain and Jiménez (1985), Palmquist (1991), Freeman III (2003) and Ekeland et al. (2002, 2004).

${ }^{6}$ For more information about the methodology used in the market study, is found "Market study for new houses in the city of Gijón” Foro Consultores Inmobiliarios S.L. (2002).
} 
has a lumber room; the floor on which the residence is located; and certain characteristics related to the quality for each residence of the sample including whether or not it has a swimming pool $\left(Q_{S W}\right)$, gardens $\left(Q_{G}\right)$, sports areas $\left(Q_{S P}\right)$, equipped kitchen $\left(Q_{K}\right)$, entry video-phone $\left(Q_{V I}\right)$ and satellite dish $\left(Q_{S A}\right)$.

The next step is to define the variables that are included in the hedonic equation. With regard to the independent variables, that is to say, the characteristics of the flat, we wish to include a reduced number of these characteristics but with the condition that the dwelling is described correctly (Butler, 1980). The independent variables of the hedonic equation are classified in four groups:

- Variables that measures the size of the flat: due to the high correlation between the floorspace of the house in square metres $\left(S_{A}\right)$ and the number of rooms ${ }^{7}\left(S_{R}\right)$, a new variable, average size of the rooms, $\left(S_{M}\right)$, is created. It is defined as the result of dividing square metres by the number of rooms. Number of rooms $\left(S_{R}\right)$, and the dummy variables garage $\left(S_{G}\right)$ and lumber room $\left(S_{L}\right)$ are also included.

- Variables that measures the quality of the house. Due to the existence of high correlations between these variables (see appendix) a measure of quality is constructed (Q). To do so, a point is given for each one of the quality-related characteristics that the house has. Thus, if the house has an entry video-phone, swimming pool and gardens, the quality variable is assigned a value of three points. The floor on which the apartment is located $\left(Q_{H}\right)$ is also included as a quality variable.

\footnotetext{
${ }^{7}$ See appendix.
} 
- Variables related to the location of the flat. Two variables are included. The first one is the distance in metres from the house to the city centre $\left(D_{C}\right)$, and the second one is the distance in metres from the house to the nearest beach ${ }^{8}\left(D_{B}\right)$.

- Variables related to the environmental surroundings of the flat. Two variables that try to measure the detrimental effects of the industry on the value of the flat are included. The first one is the distance in metres from each apartment to the factory $\left(E_{F}\right)$, where we expect that the shorter the distance to the plant, the lower the value of the apartment. This variable provides direct information on the effects of the industry on the value of the properties. The second variable is an index of air pollution of the zone in which the dwelling is located $\left(E_{A}\right)$. In order to construct this index we start from the information collected by the four automatic atmospheric contamination measurement stations located in four different places in the city ${ }^{9}$. The stations daily measure particles suspended in the atmosphere $\left(A_{P}\right)$, sulfur dioxide $\left(A_{S}\right)$, nitrogen dioxide $\left(A_{N}\right)$, carbon monoxide $\left(A_{C}\right)$ and lead $\left(A_{L}\right)$. The previous variables are highly correlated as can be observed from the correlation matrix that appears in the appendix. For this reason we construct an index of atmospheric contamination by adding the average of the standardized annual values of each one of the atmospheric polluting agents. It is standardized by dividing each value between the sample highest value. The greatest the contamination of the zone, the greatest the value of the index and the smallest value of the dwelling, ceteris paribus. This variable does not directly relate the effects of the industry with the value of the dwellings, since atmospheric contamination is not caused solely by the iron and steel industry but also by road traffic and other industries of the

\footnotetext{
${ }^{8}$ There are three beaches in the town.

${ }^{9}$ One can see Local Observatory $n^{\circ} 16$. Gijón City council for information on the environmental stations.
} 
zone as well ${ }^{10}$. Nevertheless, we assume that a reduction of the emissions of polluting agents on the part of the iron and steel industry has positive effects on the atmosphere.

The dependent variable is the sale price in euros of the dwelling excluding taxes, $(P)$.

Two assumptions have to be made: the first one is that the entire urban area can be treated as a single market; and the second is that the housing market is at or near equilibrium (Palmquist, 1991; Parsons, 1986).

The choice of functional form in hedonic pricing method has been a major concern due to the lack of guidance from economic theory about the intricate relationship between housing price and its multiple attributes. Functional forms for the hedonic price function that have been proposed in the literature include the linear (De Borgert, 1986; King 1976; Parsons 1986), the quadratic (Witte et al. 1979), the loglinear (Nelson, 1978), the semi-log (Palmquist, 1984), and the Box-Cox transformation (Blomquist and Worley, 1981; Goodman, 1978; Goodman and Kawai, 1984; Linneman, 1981; Quigley, 1982). In recent years a number of nonparametric approaches have been proposed (Ekeland et al. 2002, 2004). It is believed that Box-Cox transformations and nonparametric approaches could yield a better fit of the data than other transformations. Nevertheless, this requires complicated transformation processes which could introduce more random errors and for this reason that the search was restrictive to the four forms most frequently used: linear, log-lin, lin-log and log-linear.

The estimed equations are the following ones:

- linear model, $P=\alpha_{0}+\alpha_{1} S_{R}+\alpha_{2} S_{M}+\alpha_{3} S_{G}+\alpha_{4} S_{L}+\alpha_{5} Q+\alpha_{6} Q_{H}+\alpha_{7} D_{C}+\alpha_{8} D_{B}+\alpha_{9} E_{F}+\alpha_{10} E_{A}+v_{i}$

${ }^{10}$ Unfortunately, we lack of traffic density data for each town area. 
- log-lin model,

$\ln P=\alpha_{0}+\alpha_{1} S_{R}+\alpha_{2} S_{M}+\alpha_{3} S_{G}+\alpha_{4} S_{L}+\alpha_{5} Q+\alpha_{6} Q_{H}+\alpha_{7} D_{C}+\alpha_{8} D_{B}+\alpha_{9} E_{F}+\alpha_{10} E_{A}+v_{i}$

- lin-log model,

$P=\alpha_{0}+\alpha_{1} S_{R}+\alpha_{2} \ln S_{M}+\alpha_{3} S_{G}+\alpha_{4} S_{L}+\alpha_{5} Q+\alpha_{6} Q_{H}+\alpha_{7} \ln D_{C}+\alpha_{8} \ln D_{B}+\alpha_{9} \ln E_{F}+\alpha_{10}$

$\ln E_{A}+v_{\mathrm{i}}$

- log-linear model,

$\ln P=\alpha_{0}+\alpha_{1} S_{R}+\alpha_{2} \ln S_{M}+\alpha_{3} S_{G}+\alpha_{4} S_{L}+\alpha_{5} Q+\alpha_{6} Q_{H}+\alpha_{7} \ln D_{C}+\alpha_{8} \ln D_{B}+\alpha_{9} \ln E_{F}+\alpha_{10}$

$\ln E_{A}+v_{\mathrm{i}}$

where $\mathrm{v}_{\mathrm{i}}$ is the term of habitual error, $\alpha_{0}$ is the constant and the $\alpha^{\prime} \mathrm{s}$ are the coefficients of variables.

The estimation method is ordinary least squares (OLS) and the software LIMDEP is used.

The log-linear model was found to be the best model on the basis of the summary statistics, and we only report the results for this specification ${ }^{11}$. The results of the other functional forms are available on request to the author.

${ }^{11}$ The results of the other functional forms are available on request to the author. 
Table 1. Results of regression of log-linear model.

\begin{tabular}{|l|l|l|}
\hline Variables & Coefficient & t-ratio $^{\text {a)b }}$ \\
\hline$\alpha_{0}$ & 11.1 & $8.2 * * *$ \\
$\mathrm{~S}_{\mathrm{R}}$ & 0.30 & $8.75^{* * *}$ \\
$\mathrm{~S}_{\mathrm{M}}$ & 0.59 & $2.12^{* *}$ \\
$\mathrm{~S}_{\mathrm{G}}$ & 0.09 & $2.4 * *$ \\
$\mathrm{~S}_{\mathrm{L}}$ & 0.02 & 0.47 \\
$\mathrm{Q}$ & -0.003 & -0.21 \\
$\mathrm{Q}_{\mathrm{H}}$ & 0.04 & $3.84 * * *$ \\
$\mathrm{D}_{\mathrm{C}}$ & -0.17 & $-5.2^{* * *}$ \\
$\mathrm{D}_{\mathrm{B}}$ & -0.14 & $-6.1 * * *$ \\
$\mathrm{E}_{\mathrm{F}}$ & 0.25 & $2.7 * * *$ \\
$\mathrm{E}_{\mathrm{A}}$ & -0.90 & $-2.75^{* * *}$ \\
\hline $\mathrm{R}^{2}$ Adj. & 76.2 & \\
F -RATIO & 53.91 & \\
$(\mathrm{p})$-Value & 0.000 & \\
\cline { 1 - 2 } & & \\
\cline { 1 - 2 } & & \\
\hline
\end{tabular}

a)***Significant at $1 \%$ level, **Significant at $5 \%$ level. b) Heteroskedasticity-robust estimates (White Method). All variables are in natural log form, except the dummy and ordinal variables, $n=166$.

The results are, in principle, satisfactory, and the effectiveness of the Rosen (1974) method is shown, confirming the existence of an implicit market for house characteristics, including environmental ones. The model explains a high percentage of the price of the house, which indicates that the functional form and the characteristics included are reasonable. The set of explanatory variables account for $76 \%$ of the price variable and the F-ratio test indicates that the model fits properly. All the coefficients have the expected signs and are significant at the conventional levels, except for the lumber room and the quality. Maybe the non meaningfulness of the lumber room is due to the small data variation, since 166 out of 143 houses have got lumber room. As far as 
quality is concerned, perhaps something similar does happen since every house is new. Therefore, their quality level is all alike.

The positive signs of the coefficients indicate that the market favorably values an increase of the characteristic, and vice versa for negative. Thus, a flat with three rooms will have a higher price than another one with two rooms, ceteris paribus. Whereas an apartment located 1000 metres away from the town centre has a lower value than a similar apartment located 900 metres away.

As a log-linear functional form is used, the coefficients of continuous the variables are elasticities, maintaining all the other characteristics constant. Thus, if the average size of the rooms increases by $10 \%$, the price of the flat rises by $5.9 \%$ ceteris paribus. Similarly, the price increases by $2.5 \%$ when the distance from the plant increases by $10 \%$, maintaining all the other characteristics constant.

On the other hand, if the distance from the city centre increases by $10 \%$, the price of the flat falls by $1.7 \%$ ceteris paribus. When the dwelling is located $10 \%$ further away from the nearest beach, its price falls by $1.4 \%$. The apartment price diminishes by $9 \%$ when the atmospheric contamination increases by $10 \%$ since the coefficient is negative.

In the case of the discrete variables, the estimated coefficient is interpreted as a multiplying coefficient, after exponent. For example, the existence of a garage means that the price of the flat is multiplied by 1.09 ceteris paribus. Similarly, an increase in the floor level on which the dwelling is located multiplies the price of the dwelling by 1.04 , ceteris paribus. Finally, the price of an apartment increases a 35\% when it has got one more room. 
The variables that contribute most to the price of the dwelling are those that measure the size of the dwelling and the atmosphere quality. The first ones are related to the basic necessity of lodging. Once this necessity is satisfied, the characteristics most valued by the market are the one related to the environmental surroundings ${ }^{12}$. Environmental improvement will produce significant increases in the prices of the dwelling, capitalizing the benefit of the improvement in their value. Thus, we can change the characteristics to see how the prices of the dwelling change.

In table 2 the variations in the price of a flat with standard characteristics are calculated by increasing the distance from the factory ${ }^{13}$.

The change in the distance variable could be achieved by a policy of relocating the industry, by reducing its size or by dismantling it completely.

Table 2. Variation of the price before changes in the distance

\begin{tabular}{|c|c|c|}
\hline Distance $(\mathrm{m})$ & Price $(€)$ & Dwelling price increase (\%) \\
\hline 500 & 179046 & \\
1000 & 212989 & 18.95 \\
1500 & 235625 & 31.6 \\
2000 & 253469 & 41.56 \\
2500 & 268069 & 49.72 \\
3000 & 280660 & 56.75 \\
4000 & 301643 & 68.47 \\
\hline
\end{tabular}

\footnotetext{
${ }^{12}$ Bilbao, C. (2001) and Bilbao, A., Bilbao, C. and Labeaga, J.M. (2005) also obtain similar results as far as the importance of the variables is concerned for the town of Gijón. Unfortunately, comparisons cannot be made since the variables and the years are different from this work's.

${ }^{13}$ The characteristics of the standard house are the averages of the characteristics in the sample. The standard house has 72 square metres, four pieces with an average size of 16,26 metres, a garage and storeroom, a quality index of 2, is on a second floor, is situated 1600 metres away from the town centre, 1300 metres away from the nearest beach, 5400 metres away from the factory and it has an of atmospheric pollution index of 4.46. The simulation uses the values of the standard apartment characteristics except for the distance to the iron and steel plant, for which a value of 500 metres is used.
} 
As can be observed in table 2, the increases in the price of the flat as it is moved further from the plant are quite high. Proximity to the plant is valued in a very negative way by the market. Any policy of increasing the distance to the plant or dismantling the plant must take into account the environmental gain that is materialized in the price of the flat. For example, a policy that moved the plant 2000 metres further from the town centre would increase the value of the apartments by $40 \%$.

It is also observed how the price of the flat increases at a decreasing rate as we move away from the plant. This means that the flats next to the factory are those that would be more favoured by an increase in the distance to the factory, a reduction in its size or its complete dismantling. The area nearest to the factory is that which suffers the highest environmental and aesthetic impact in the whole city. It is logical that it is in this area that any measure of environmental improvement will produce the greatest benefits. On the other hand, it is an area where there is a lot of building land which has not been very attractive until now due to the characteristics of the area. The recuperation of this land would probably activate construction activity. This would reduce the excess of housing demand in the town.

It is also possible to simulate how the price of the standard apartment varies due to reductions in atmospheric contamination through, for example, a reduction in factory production or the installation of anticontamination equipment. We start by assuming a apartament with standard characteristics except for the atmospheric pollution maximum index. Table 3 presents the results. 
Table 3. Variation of the price before changes in atmospheric contamination.

\begin{tabular}{|l|l|l|}
\hline Contamination reduction (units) & Price $(€)$ & Dwelling price increase (\%) \\
\hline & & \\
0.1 & 308584 & \\
0.2 & 314581 & 1.94 \\
0.3 & 320840 & 3.97 \\
0.4 & 327387 & 6.09 \\
0.5 & 334201 & 8.3 \\
\hline
\end{tabular}

The price of the flat increases at an almost constant rate as contamination is reduced. Decreases in atmospheric contamination will therefore benefit all areas of the city in a similar way. If a measure that reduced the contamination index by 0.1 were implemented (for example, through a reduction of the production of the factory) the price of the new flat would increase by $1.94 \%$. Prices would increase by $6 \%$ if is the contamination index was reduced by 0.3 units and by $8.3 \%$ if the reduction were 0.4 units and so on.

This is, of course, a partial equilibrium analysis. Other effects that a reduction of the production of the factory would produce have not been considered. For example, closing the plant might result in significant loss of jobs and reduction in demand for dwelling in the city.

\section{General discussion and conclusions}

On many occasions it is important to know how individuals value environmental quality, such as for example, when it is necessary to decide on the creation of a green area or the dismantling of a polluting industry. Not taking into account the effect of 
these types of actions on the welfare of the consumers can result in erroneous decisions being taken from the economic point of view.

This work has evaluated the effects that an iron and steel plant has on the price of new apartment, applying the hedonic pricing method (Rosen, 1974) to the environmental field. The method has shown to be effective in carrying out this type of valuation. Many studies have been conducted using the hedonic pricing method to evaluate environmental externalities. However, there are no significant studies about the effects on environmental quality caused by iron and steel industries.

The results indicate that the industry exerts very negative effects on the environment that are reflected in the prices of the surrounding dwellings. Therefore, any measure aimed at reducing the contamination of the industry, increasing its distance from the city centre or dismantling the plant will produce an increase in the quality of the environmental that will be transmitted to house prices. In addition, the flats nearest to the factory are those that would benefit most from an improvement in the environment. The recovery of the area surrounding the industry would not only produce great benefits for already built dwellings but it would also activate construction in a city with a shortage of dwellings. 


\section{Appendix}

Table A.1. Correlation matrix for listed variables

\begin{tabular}{|c|c|c|c|c|c|c|c|c|}
\hline & $P$ & $S_{R}$ & $S_{A}$ & $S_{G}$ & $S_{L}$ & $Q_{s W}$ & $Q_{G}$ & $Q_{S P}$ \\
\hline$P$ & 1.0000 & 0.5119 & 0.6329 & -0.0149 & -0.0211 & 0.1334 & 0.0369 & -0.0313 \\
\hline$S_{R}$ & 0.5112 & 1.0000 & 0.8808 & 0.1938 & 0.1467 & 0.0751 & 0.1300 & 0.0876 \\
\hline$S_{A}$ & 0.6329 & 0.8808 & 1.0000 & 0.3001 & 0.0676 & 0.1802 & 0.1961 & 0.0945 \\
\hline$S_{G}$ & -0.0149 & 0.1938 & 0.3009 & 1.0000 & 0.2930 & 0.2129 & 0.2910 & 0.2050 \\
\hline$S_{L}$ & -0.2107 & 0.1467 & 0.0676 & 0.2930 & 1.0000 & 0.1264 & 0.1728 & 0.1217 \\
\hline$Q_{S W}$ & 0.1334 & 0.0751 & 0.1802 & 0.2129 & 0.1264 & 1.0000 & 0.7313 & 0.6605 \\
\hline$Q_{G}$ & -0.0369 & 0.0876 & 0.0945 & 0.2049 & 0.1217 & 0.6604 & 0.7042 & 0.7042 \\
\hline$Q_{S P}$ & -0.0031 & 0.0876 & 0.0946 & 0.2050 & 0.1217 & 0.6605 & 0.7042 & 1.0000 \\
\hline$Q_{K}$ & 0.1272 & 0.0327 & 0.0796 & 0.1755 & -0.1310 & 0.1029 & 0.1407 & 0.0991 \\
\hline$Q_{V I}$ & 0.0874 & 0.1788 & 0.2092 & 0.3718 & 0.1618 & 0.2273 & 0.2269 & 0.2999 \\
\hline$Q_{S A}$ & 0.0643 & 0.1912 & 0.2102 & 0.4620 & 0.2146 & 0.2207 & 0.4014 & 0.2007 \\
\hline$Q$ & 0.1438 & 0.1746 & 0.2207 & 0.4226 & 0.2169 & 0.6661 & 0.7290 & 0.7071 \\
\hline$Q_{H}$ & 0.2307 & 0.1313 & 0.1563 & -0.0989 & -0.0634 & -0.0832 & -0.1146 & -0.1164 \\
\hline$D_{C}$ & -0.4224 & 0.0662 & 0.0517 & 0.4403 & 0.4117 & 0.0389 & 0.1070 & 0.0768 \\
\hline$D_{B}$ & -0.3415 & 0.1347 & 0.0974 & 0.3961 & 0.4181 & 0.1294 & 0.2285 & 0.2005 \\
\hline$E_{F}$ & 0.3647 & 0.0470 & 0.1200 & -0.0332 & -0.1310 & 0.3843 & 0.2370 & 0.1736 \\
\hline$E_{A}$ & -0.1446 & -0.0940 & -0.2120 & -0.3459 & -0.2003 & -0.6564 & -0.5588 & -0.4141 \\
\hline$A_{P}$ & 0.1655 & -0.1224 & -0.1942 & -0.3905 & -0.1381 & -0.0070 & -0.1483 & -0.0956 \\
\hline$A_{S}$ & 0.0365 & -0.0562 & -0.1387 & -0.3383 & -0.2858 & -0.4726 & -0.4013 & -0.2975 \\
\hline$A_{N}$ & -0.0714 & -0.0062 & -0.0634 & -0.1660 & -0.2167 & -0.5183 & -0.3723 & -0.2830 \\
\hline$A_{C}$ & -0.0887 & -0.0999 & -0.2180 & -0.3858 & -0.2304 & -0.6140 & -0.5389 & -0.3978 \\
\hline
\end{tabular}




\begin{tabular}{|c|c|c|c|c|c|c|c|c|}
\hline$A_{L}$ & -0.3719 & -0.0127 & -0.0465 & 0.1333 & 0.1788 & -0.3435 & 0.2300 & -0.1765 \\
\hline & $Q_{K}$ & $Q_{V I}$ & $Q_{S A}$ & $Q$ & $Q_{H}$ & $D_{C}$ & $D_{B}$ & $E_{F}$ \\
\hline$E_{A}$ & -0.1565 & -0.2882 & -0.3079 & -0.5298 & 0.0097 & -0.2733 & -0.1740 & -0.4281 \\
\hline$Q_{K}$ & 1.0000 & 0.1672 & 0.2202 & 0.2848 & -0.0084 & -0.0084 & -0.0925 & 0.0641 \\
\hline$Q_{V I}$ & 0.1672 & 1.0000 & 0.4470 & 0.6280 & 0.0660 & 0.0864 & 0.2775 & 0.1028 \\
\hline$Q_{S A}$ & 0.2202 & 0.4470 & 1.0000 & 0.6446 & -0.0080 & 0.2466 & 0.2200 & -0.0615 \\
\hline$Q$ & 0.2848 & 0.6280 & 0.6446 & 1.0000 & -0.0388 & 0.0854 & 0.2213 & 0.2076 \\
\hline$Q_{H}$ & -0.0084 & 0.0660 & -0.0080 & -0.0388 & 1.0000 & 0.0360 & -0.0083 & -0.0974 \\
\hline$D_{C}$ & -0.0084 & 0.0864 & 0.2466 & 0.0854 & 0.0360 & 1.0000 & 0.4132 & -0.5015 \\
\hline$D_{B}$ & -0.0925 & 0.2775 & 0.2200 & 0.2213 & -0.0083 & 0.4132 & 1.0000 & 0.0582 \\
\hline$D_{F}$ & 0.0641 & 0.1028 & -0.0615 & 0.2076 & -0.0974 & -0.5015 & 0.0582 & 1.0000 \\
\hline$A_{P}$ & -0.0478 & -0.1762 & -0.3360 & -0.1557 & -0.0366 & -0.4055 & -0.5665 & 0.3008 \\
\hline$A_{S}$ & -0.1524 & -0.1810 & -0.3206 & -0.3866 & -0.0445 & -0.5993 & -0.0714 & 0.0050 \\
\hline$A_{N}$ & -0.1362 & -0.1216 & -0.1703 & -0.3511 & -0.0200 & -0.3745 & 0.1797 & -0.2108 \\
\hline$A_{C}$ & -0.1600 & -0.2847 & -0.3460 & -0.5139 & -0.0051 & -0.3799 & -0.2185 & -0.3045 \\
\hline$A_{L}$ & 0.0013 & -0.1146 & 0.1438 & -0.2017 & 0.1025 & 0.6710 & 0.0781 & -0.8536 \\
\hline
\end{tabular}

$\begin{array}{cccccc}A_{P} & A_{S} & A_{N} & A_{C} & A_{L} & E_{A}\end{array}$

$\begin{array}{lllllll}E_{A} & 0.2188 & 0.8618 & 0.8139 & 0.9866 & 0.2067 & 1.0000\end{array}$

$\begin{array}{lllllll}A_{P} & 1.0000 & 0.2800 & -0.1976 & 0.3449 & -0.5266 & 0.2188\end{array}$

$\begin{array}{lllllll}A_{S} & 0.2800 & 1.0000 & 0.8822 & 0.9103 & -0.2673 & 0.8618\end{array}$

$\begin{array}{lllllll}A_{N} & -0.1976 & 0.8822 & 1.0000 & 0.7937 & 0.0531 & 0.8139\end{array}$

$\begin{array}{lllllll}A_{C} & 0.3449 & 0.9103 & 0.7937 & 1.0000 & 0.0516 & 0.9866\end{array}$

$\begin{array}{lllllll}A_{L} & -0.5266 & -0.2673 & 0.0531 & 0.0516 & 1.0000 & 0.2067\end{array}$ 


\section{References}

Anderson L M, Cordell H K, 1988, "Influence of trees on residential property values in Athens, Georgia (USA): a survey based on actual sales price" Landscape and Urban Planning 15 153-164.

Ball M J, 1973, "Recent Empirical Work on the Determinants of Relative House Prices" Urban Studies 10 213-233.

Bengochea-Morancho A, 2003, “A hedonic valuation of urban green spaces” Landscape and Urban Planning 66 35-41.

Benson E D, Hansen, J L, Schwartz A L, Smersh G T, 1998, "Pricing residential amenities: the value of a view" Journal of Real Estate Finance and Economics $1655-73$.

Bilbao C, 2001, "El otro exceso de gravamen. Un análisis empírico para las políticas de vivienda” Revista de Economía Aplicada, 27 31-61.

Bilbao A, Bilbao C, Labeaga J M, 2005, "The exceso burden associated to characteristics of the goods: Application to housing demand" Documentos de trabajo de FEDEA 2005-09.

Bourassa S C, Hoesli M, Sun J, 2004, "What's in a view?" Environment and Planning A 36(8) $1427-1450$

Brasington D M, Hite D, 2005, "Demand for environmental quality: a spatial hedonic analysis" Regional Science and Urban Economics 35 57-82.

Brookshire D S, Thayer M A, Schulze W D, D'Arge R C, 1982, "Valuing public goods: a comparison of survey and hedonic approaches" The American Economic Review 72 165-177. 
Butler R V, 1980, "Cross-sectional variation in the hedonic relationship for urban housing markets" Journal of Regional Science 20 439-453.

Court A T, 1939, "Hedonic price indexes with automotive", in General Motors, The Dynamics of Automobile Demand (New York) pp 99-117.

Dale L, Murdoch J C, Thayer M A, Waddell P A, 1999, "Do Property Values Rebound from Environmental Stigmas? Evidence from Dallas" Land Economics 75 311326.

De Borgert B, 1986, "Estimating the benefits of public-housing programs: a characteristics approach” Journal of Regional Science 26 761-773.

Ekeland I, Heckman J, Nesheim L, 2002, "Identifying hedonic models" The American Economic Review 92 304-309.

Ekeland I, Heckman J, Nesheim L, 2004, “Identification and estimation of hedonic models" Journal of Political Economy 1 60-109.

Espey E, Lopez H, 2000, "The impact of airport noise and proximity on residential property values" Growth and Change 31 408-419.

Follain J R, Jimenez E, 1985, "Estimating the demand for housing characteristics: A survey and critique", Regional Science and Urban Economics 15 77-107.

Folland S, Hough R, 2000, "Externalities of nuclear power plants: further evidence", Regional Science and Urban Economics 40 735-753.

Freeman III A M, 2003 The mesurement of environmental and resource values, theory and methods, Resources for the Future, (Washinton, D.C)

Gamble H B, Downing R H, 1982, "Effects of nuclear power plants on residential proterty values", Journal of Regional Science 22, 457-478. 
Gawande K, Jenkins-Smith H, 2001, "Nuclear Waste Transport and Residential Property Value: Estimating the Effects of Perceived Risks", Journal of Environmental Economics and Management 42, 207-233.

Gayer T, Hamilton J T, Viscusi, W K, 2000, "Private values of risk tradeoffs at superfund sites: housing market evidence on learning about risk" Review of Economics and Statistics 82 439-451.

Goméz C M, 1996, "Valuation of urban green spaces: the hedonic prices method", in Management of Spaces Naturales Eds D Azqueta Oyarzun, L Peréz Peréz (Mcgraw-Hill, Madrid) pp 51-71.

Goodman A C, 1978, "Hedonic Prices, Price Indices and Housing Markets", Journal of Urban Economics 5 471-484.

Goodman A C, Kawai M, 1984, ”Estimation and Policy Implications of Rental Housing Demand", Journal of Urban Economics 16 76-90.

Graves P, Murdoch J C, Thayer M A, Walkman D, 1988, "The robustness of hedonic estimation: urban air quality" Land Economics 64 220-233

Griliches Z, 1971 Price Indices and Quality Change (Havard, Cambridge, Massachusetts).

Hite D, Chern W, Hitzhusen F, Randall A, 2001, "Property-Value Impacts of an Environmental Disamenity: the Case of Landfills" Journal of Real Estate Finance and Economics 22 185-202.

Hughes W T, Sirmans C F, 1992 "Traffic externalities and single-family house” Journal of Regional Science 32 487-500. 
Ihlanfeldt K R, Taylor L O, 2004, "Externality effects of small-scale hazardous waste sites: evidence from urban commercial property markets" Journal of Evironmental Economics and Management 47 117-139.

Jim C Y, Chen S S, 2003, “Comprehensive greenspace planning based on landscape ecology principles in compact Nanjing city, China" Landscape Urban Planning $6595-116$.

Johansson P O, 1993 Cost-Benefit Analysis of enviromental change (Cambridge University Press, Cambridge).

Ketkar K, 1992, "Hazardous Wastes Sites and Property Values in the State of New Jersey" Applied Economics 24 647-659.

Kiel K, Zabel J, 2001, “Estimating the Economics Benefits of Cleaning Up Superfund Sites: The Case of Woburn, Massachusetts", Journal of Real Estate Finance and Economics 22 163-184.

King T A, 1976, "The demand for Housing: A Lancastrian approach" Southern Economic Journal 43 1077-1087.

Kohlhase J E, 1991, “The impact of Toxic Wastes Sites on Housing Values”, Journal of Urban Economics 30 1-26.

Lancaster K J, 1966, “A new appoach to consumer theory”, Journal of Political Economy 74 132-157.

Letombe G, Zuindeau B, 2005, "Impact of polluting industries on residential property values : le cas of Metaleurop-Nord" Économie Appliquée LVIII 161-191.

Linneman P, 1981, "The Demand for Residence Site Characteristics", Journal of Urban Economics 9 129-148. 
Luttik J, 2000, “The value of trees, water and open space as reflected by house prices in The Netherlands" Landscape and Urban Planning 48 161-167.

McLeod P B, 1984, "The demand for local amenity: an hedonic price analysis" Environment and Planning A 16 389-400.

McMillan M L, 1979, “Estimates of households preferences for enviromental quality and other housing characteristics from a system of demand equations" Scandinavian Journal of Economics 81 174-187.

McMillan M L, Reid B G, Gillen D W, 1980, “An Extension of the Hedonic Approach for Estimating the Value of Quiet" Land Economics 56 315-327.

Michaels R G, Smith V K, 1990, "Market Segmentation and Valuing Amenities with Hedonic Models: The Case of Hazardous Wastes Sites" Journal of Urban Economics 28 223-242.

More T A, Stevens T, Allen P G, 1988 "Valuation of urban parks" Landscape and Urban Planning 15 139-152.

Nelson J P, 1978 "Residential Choice, Hedonic Prices, and the Demand for Urban Air Quality” Journal of Urban Economics 5 357-369.

Ohsfeldt R L, Smith B A, 1990 “Calculating Elasticities from Structural Parameters in Implict Markets" Journal of Urban Economics 27 212-221.

Palmquist R B, 1984, "Estimating the demand for the characteristics of housing", Review of Economics and Statistics 64, 394-404.

Palmquist R B, 1991, "Hedonic Methods", in Measuring the Demand for Environmental Quality Eds. JB Braden, CD Kolstad, Elsevier Science Publishers B.V. (North-Holland) pp 77-120. 
Parsons G R, 1986, "An Almost Ideal Demand System for Housing Attributes", Southern Economic Journal 53 347-363.

Powe N A, Garrod G D, Willis K G, 1995, "Valuation of urban amenities using an hedonic price model" Journal of Property Research 12 137-147.

Quigley J M, 1982, "Nonlinear Budget Constrains and Consumer Demand: An Application to Public Programs for Residential Housing”, Journal of Urban Economics 12 177-201.

Ridker R G, 1967 Economic Cost of Air Pollution: Studies and Measurement (New York, Praeger).

Rosen S, 1974, "Hedonic Prices and Implicit Markets: Product Differentiation in Pure Competition” Journal of Political Economy 1 35-55.

Smith V K, Deyak T A, 1975, "Measuring the impact of air pollution on property values" Journal of Regional Science 15, 277-288

Smith V K, Huang J C, 1995 "Can markets value air quality? A meta-analysis of hedonic property value models" Journal of Political Economy 103 209-227.

Tajima K, 2003, "New estimates of the demand for urban green space: implications for valuing the environmental benefits of Boston's big dig project" Journal of Urban Affairs 25 641-655.

Tyrväinen L, 1997, "The amenity value of the urban forest: an application of the hedonic pricing method" Landscape and Urban Planning 37 211-222.

Willis K G, Garrod G D, 1993, "The contribution of trees and woodland to the value of property" Journal of Arboriculture 17 211-219. 
Witte A D, Sumka H J, Erekson H, 1979, “An estimate of a structural hedonic price model of the housing market: An application of Rosen's theory of implicit markets" Econometrica 47 1151-1173. 


\section{DOCUMENTOS DE TRABAJO}

\section{Últimos números publicados}

159/2000 Participación privada en la construcción y explotación de carreteras de peaje Ginés de Rus, Manuel Romero y Lourdes Trujillo

160/2000 Errores y posibles soluciones en la aplicación del Value at Risk Mariano González Sánchez

161/2000 Tax neutrality on saving assets. The spahish case before and after the tax reform Cristina Ruza y de Paz-Curbera

162/2000 Private rates of return to human capital in Spain: new evidence F. Barceinas, J. Oliver-Alonso, J.L. Raymond y J.L. Roig-Sabaté

163/2000 El control interno del riesgo. Una propuesta de sistema de límites riesgo neutral Mariano González Sánchez

164/2001 La evolución de las políticas de gasto de las Administraciones Públicas en los años 90 Alfonso Utrilla de la Hoz y Carmen Pérez Esparrells

165/2001 Bank cost efficiency and output specification Emili Tortosa-Ausina

166/2001 Recent trends in Spanish income distribution: A robust picture of falling income inequality Josep Oliver-Alonso, Xavier Ramos y José Luis Raymond-Bara

167/2001 Efectos redistributivos y sobre el bienestar social del tratamiento de las cargas familiares en el nuevo IRPF

Nuria Badenes Plá, Julio López Laborda, Jorge Onrubia Fernández

168/2001 The Effects of Bank Debt on Financial Structure of Small and Medium Firms in some European Countries Mónica Melle-Hernández

169/2001 La política de cohesión de la UE ampliada: la perspectiva de España Ismael Sanz Labrador

170/2002 Riesgo de liquidez de Mercado Mariano González Sánchez

171/2002 Los costes de administración para el afiliado en los sistemas de pensiones basados en cuentas de capitalización individual: medida y comparación internacional.

José Enrique Devesa Carpio, Rosa Rodríguez Barrera, Carlos Vidal Meliá

172/2002 La encuesta continua de presupuestos familiares (1985-1996): descripción, representatividad y propuestas de metodología para la explotación de la información de los ingresos y el gasto. Llorenc Pou, Joaquín Alegre

173/2002 Modelos paramétricos y no paramétricos en problemas de concesión de tarjetas de credito. Rosa Puertas, María Bonilla, Ignacio Olmeda 
174/2002 Mercado único, comercio intra-industrial y costes de ajuste en las manufacturas españolas. José Vicente Blanes Cristóbal

175/2003 La Administración tributaria en España. Un análisis de la gestión a través de los ingresos y de los gastos.

Juan de Dios Jiménez Aguilera, Pedro Enrique Barrilao González

176/2003 The Falling Share of Cash Payments in Spain.

Santiago Carbó Valverde, Rafael López del Paso, David B. Humphrey

Publicado en "Moneda y Crédito” n 217, pags. 167-189.

177/2003 Effects of ATMs and Electronic Payments on Banking Costs: The Spanish Case.

Santiago Carbó Valverde, Rafael López del Paso, David B. Humphrey

178/2003 Factors explaining the interest margin in the banking sectors of the European Union.

Joaquín Maudos y Juan Fernández Guevara

179/2003 Los planes de stock options para directivos y consejeros y su valoración por el mercado de valores en España.

Mónica Melle Hernández

180/2003 Ownership and Performance in Europe and US Banking - A comparison of Commercial, Cooperative \& Savings Banks.

Yener Altunbas, Santiago Carbó y Phil Molyneux

181/2003 The Euro effect on the integration of the European stock markets.

Mónica Melle Hernández

182/2004 In search of complementarity in the innovation strategy: international R\&D and external knowledge acquisition.

Bruno Cassiman, Reinhilde Veugelers

183/2004 Fijación de precios en el sector público: una aplicación para el servicio municipal de suministro de agua.

Ma Ángeles García Valiñas

184/2004 Estimación de la economía sumergida es España: un modelo estructural de variables latentes.

Ángel Alañón Pardo, Miguel Gómez de Antonio

185/2004 Causas políticas y consecuencias sociales de la corrupción.

Joan Oriol Prats Cabrera

186/2004 Loan bankers' decisions and sensitivity to the audit report using the belief revision model.

Andrés Guiral Contreras and José A. Gonzalo Angulo

187/2004 El modelo de Black, Derman y Toy en la práctica. Aplicación al mercado español.

Marta Tolentino García-Abadillo y Antonio Díaz Pérez

188/2004 Does market competition make banks perform well?.

Mónica Melle

189/2004 Efficiency differences among banks: external, technical, internal, and managerial Santiago Carbó Valverde, David B. Humphrey y Rafael López del Paso 
190/2004 Una aproximación al análisis de los costes de la esquizofrenia en españa: los modelos jerárquicos bayesianos

F. J. Vázquez-Polo, M. A. Negrín, J. M. Cavasés, E. Sánchez y grupo RIRAG

191/2004 Environmental proactivity and business performance: an empirical analysis

Javier González-Benito y Óscar González-Benito

192/2004 Economic risk to beneficiaries in notional defined contribution accounts (NDCs)

Carlos Vidal-Meliá, Inmaculada Domínguez-Fabian y José Enrique Devesa-Carpio

193/2004 Sources of efficiency gains in port reform: non parametric malmquist decomposition tfp index for Mexico

Antonio Estache, Beatriz Tovar de la Fé y Lourdes Trujillo

194/2004 Persistencia de resultados en los fondos de inversión españoles

Alfredo Ciriaco Fernández y Rafael Santamaría Aquilué

195/2005 El modelo de revisión de creencias como aproximación psicológica a la formación del juicio del auditor sobre la gestión continuada

Andrés Guiral Contreras y Francisco Esteso Sánchez

196/2005 La nueva financiación sanitaria en España: descentralización y prospectiva

David Cantarero Prieto

197/2005 A cointegration analysis of the Long-Run supply response of Spanish agriculture to the common agricultural policy

José A. Mendez, Ricardo Mora y Carlos San Juan

198/2005 ¿ ¿Refleja la estructura temporal de los tipos de interés del mercado español preferencia por la liquidez?

Magdalena Massot Perelló y Juan M. Nave

199/2005 Análisis de impacto de los Fondos Estructurales Europeos recibidos por una economía regional: Un enfoque a través de Matrices de Contabilidad Social

M. Carmen Lima y M. Alejandro Cardenete

200/2005 Does the development of non-cash payments affect monetary policy transmission?

Santiago Carbó Valverde y Rafael López del Paso

201/2005 Firm and time varying technical and allocative efficiency: an application for port cargo handling firms

Ana Rodríguez-Álvarez, Beatriz Tovar de la Fe y Lourdes Trujillo

202/2005 Contractual complexity in strategic alliances

Jeffrey J. Reuer y Africa Ariño

203/2005 Factores determinantes de la evolución del empleo en las empresas adquiridas por opa

Nuria Alcalde Fradejas y Inés Pérez-Soba Aguilar

204/2005 Nonlinear Forecasting in Economics: a comparison between Comprehension Approach versus

Learning Approach. An Application to Spanish Time Series

Elena Olmedo, Juan M. Valderas, Ricardo Gimeno and Lorenzo Escot 
205/2005 Precio de la tierra con presión urbana: un modelo para España

Esther Decimavilla, Carlos San Juan y Stefan Sperlich

206/2005 Interregional migration in Spain: a semiparametric analysis

Adolfo Maza y José Villaverde

207/2005 Productivity growth in European banking

Carmen Murillo-Melchor, José Manuel Pastor y Emili Tortosa-Ausina

208/2005 Explaining Bank Cost Efficiency in Europe: Environmental and Productivity Influences.

Santiago Carbó Valverde, David B. Humphrey y Rafael López del Paso

209/2005 La elasticidad de sustitución intertemporal con preferencias no separables intratemporalmente: los casos de Alemania, España y Francia.

Elena Márquez de la Cruz, Ana R. Martínez Cañete y Inés Pérez-Soba Aguilar

210/2005 Contribución de los efectos tamaño, book-to-market y momentum a la valoración de activos: el caso español.

Begoña Font-Belaire y Alfredo Juan Grau-Grau

211/2005 Permanent income, convergence and inequality among countries

José M. Pastor and Lorenzo Serrano

212/2005 The Latin Model of Welfare: Do 'Insertion Contracts’ Reduce Long-Term Dependence?

Luis Ayala and Magdalena Rodríguez

213/2005 The effect of geographic expansion on the productivity of Spanish savings banks

Manuel Illueca, José M. Pastor and Emili Tortosa-Ausina

214/2005 Dynamic network interconnection under consumer switching costs

Ángel Luis López Rodríguez

215/2005 La influencia del entorno socioeconómico en la realización de estudios universitarios: una aproximación al caso español en la década de los noventa

Marta Rahona López

216/2005 The valuation of spanish ipos: efficiency analysis

Susana Álvarez Otero

217/2005 On the generation of a regular multi-input multi-output technology using parametric output distance functions

Sergio Perelman and Daniel Santin

218/2005 La gobernanza de los procesos parlamentarios: la organización industrial del congreso de los diputados en España

Gonzalo Caballero Miguez

219/2005 Determinants of bank market structure: Efficiency and political economy variables Francisco González

220/2005 Agresividad de las órdenes introducidas en el mercado español: estrategias, determinantes y medidas de performance

David Abad Díaz 
221/2005 Tendencia post-anuncio de resultados contables: evidencia para el mercado español Carlos Forner Rodríguez, Joaquín Marhuenda Fructuoso y Sonia Sanabria García

222/2005 Human capital accumulation and geography: empirical evidence in the European Union Jesús López-Rodríguez, J. Andrés Faíña y Jose Lopez Rodríguez

223/2005 Auditors' Forecasting in Going Concern Decisions: Framing, Confidence and Information Processing

Waymond Rodgers and Andrés Guiral

224/2005 The effect of Structural Fund spending on the Galician region: an assessment of the 1994-1999 and 2000-2006 Galician CSFs

José Ramón Cancelo de la Torre, J. Andrés Faíña and Jesús López-Rodríguez

225/2005 The effects of ownership structure and board composition on the audit committee activity: Spanish evidence

Carlos Fernández Méndez and Rubén Arrondo García

226/2005 Cross-country determinants of bank income smoothing by managing loan loss provisions

Ana Rosa Fonseca and Francisco González

227/2005 Incumplimiento fiscal en el irpf (1993-2000): un análisis de sus factores determinantes

Alejandro Estellér Moré

228/2005 Region versus Industry effects: volatility transmission

Pilar Soriano Felipe and Francisco J. Climent Diranzo

229/2005 Concurrent Engineering: The Moderating Effect Of Uncertainty On New Product Development Success

Daniel Vázquez-Bustelo and Sandra Valle

230/2005 On zero lower bound traps: a framework for the analysis of monetary policy in the 'age' of central banks

Alfonso Palacio-Vera

231/2005 Reconciling Sustainability and Discounting in Cost Benefit Analysis: a methodological proposal M. Carmen Almansa Sáez and Javier Calatrava Requena

232/2005 Can The Excess Of Liquidity Affect The Effectiveness Of The European Monetary Policy?

Santiago Carbó Valverde and Rafael López del Paso

233/2005 Inheritance Taxes In The Eu Fiscal Systems: The Present Situation And Future Perspectives. Miguel Angel Barberán Lahuerta

234/2006 Bank Ownership And Informativeness Of Earnings.

Víctor M. González

235/2006 Developing A Predictive Method: A Comparative Study Of The Partial Least Squares Vs Maximum Likelihood Techniques.

Waymond Rodgers, Paul Pavlou and Andres Guiral.

236/2006 Using Compromise Programming for Macroeconomic Policy Making in a General Equilibrium Framework: Theory and Application to the Spanish Economy.

Francisco J. André, M. Alejandro Cardenete y Carlos Romero. 
238/2006 Trade Effects Of Monetary Agreements: Evidence For Oecd Countries.

Salvador Gil-Pareja, Rafael Llorca-Vivero y José Antonio Martínez-Serrano.

239/2006 The Quality Of Institutions: A Genetic Programming Approach. Marcos Álvarez-Díaz y Gonzalo Caballero Miguez.

240/2006 La interacción entre el éxito competitivo y las condiciones del mercado doméstico como determinantes de la decisión de exportación en las Pymes.

Francisco García Pérez.

241/2006 Una estimación de la depreciación del capital humano por sectores, por ocupación y en el tiempo.

Inés P. Murillo.

242/2006 Consumption And Leisure Externalities, Economic Growth And Equilibrium Efficiency. Manuel A. Gómez.

243/2006 Measuring efficiency in education: an analysis of different approaches for incorporating non-discretionary inputs.

Jose Manuel Cordero-Ferrera, Francisco Pedraja-Chaparro y Javier Salinas-Jiménez

$244 / 2006$

Did The European Exchange-Rate Mechanism Contribute To The Integration Of Peripheral Countries?.

Salvador Gil-Pareja, Rafael Llorca-Vivero y José Antonio Martínez-Serrano

245/2006 Intergenerational Health Mobility: An Empirical Approach Based On The Echp. Marta Pascual and David Cantarero

246/2006 Measurement and analysis of the Spanish Stock Exchange using the Lyapunov exponent with digital technology.

Salvador Rojí Ferrari and Ana Gonzalez Marcos

Testing For Structural Breaks In Variance Withadditive Outliers And Measurement Errors. Paulo M.M. Rodrigues and Antonio Rubia

248/2006 The Cost Of Market Power In Banking: Social Welfare Loss Vs. Cost Inefficiency. Joaquín Maudos and Juan Fernández de Guevara

249/2006 Elasticidades de largo plazo de la demanda de vivienda: evidencia para España (1885-2000). Desiderio Romero Jordán, José Félix Sanz Sanz y César Pérez López

250/2006 Regional Income Disparities in Europe: What role for location?. Jesús López-Rodríguez and J. Andrés Faíña

251/2006 Funciones abreviadas de bienestar social: Una forma sencilla de simultanear la medición de la eficiencia y la equidad de las políticas de gasto público.

Nuria Badenes Plá y Daniel Santín González

“The momentum effect in the Spanish stock market: Omitted risk factors or investor behaviour?”. Luis Muga and Rafael Santamaría 
254/2006 Desigualdad regional en España: renta permanente versus renta corriente.

José M.Pastor, Empar Pons y Lorenzo Serrano

255/2006 Environmental implications of organic food preferences: an application of the impure public goods model.

Ana Maria Aldanondo-Ochoa y Carmen Almansa-Sáez

256/2006 Family tax credits versus family allowances when labour supply matters: Evidence for Spain. José Felix Sanz-Sanz, Desiderio Romero-Jordán y Santiago Álvarez-García

257/2006 La internacionalización de la empresa manufacturera española: efectos del capital humano genérico y específico.

José López Rodríguez

258/2006 Evaluación de las migraciones interregionales en España, 1996-2004.

María Martínez Torres

259/2006 Efficiency and market power in Spanish banking.

Rolf Färe, Shawna Grosskopf y Emili Tortosa-Ausina.

260/2006 Asimetrías en volatilidad, beta y contagios entre las empresas grandes y pequeñas cotizadas en la bolsa española.

Helena Chuliá y Hipòlit Torró.

261/2006 Birth Replacement Ratios: New Measures of Period Population Replacement. José Antonio Ortega.

262/2006 Accidentes de tráfico, víctimas mortales y consumo de alcohol. José $\mathrm{M}^{\mathrm{a}}$ Arranz y Ana I. Gil.

263/2006 Análisis de la Presencia de la Mujer en los Consejos de Administración de las Mil Mayores Empresas Españolas.

Ruth Mateos de Cabo, Lorenzo Escot Mangas y Ricardo Gimeno Nogués.

264/2006 Crisis y Reforma del Pacto de Estabilidad y Crecimiento. Las Limitaciones de la Política Económica en Europa.

Ignacio Álvarez Peralta.

265/2006 Have Child Tax Allowances Affected Family Size? A Microdata Study For Spain (1996-2000). Jaime Vallés-Giménez y Anabel Zárate-Marco.

266/2006 Health Human Capital And The Shift From Foraging To Farming. Paolo Rungo.

267/2006 Financiación Autonómica y Política de la Competencia: El Mercado de Gasolina en Canarias. Juan Luis Jiménez y Jordi Perdiguero.

268/2006 El cumplimiento del Protocolo de Kyoto para los hogares españoles: el papel de la imposición sobre la energía.

Desiderio Romero-Jordán y José Félix Sanz-Sanz.

269/2006 Banking competition, financial dependence and economic growth Joaquín Maudos y Juan Fernández de Guevara

270/2006 Efficiency, subsidies and environmental adaptation of animal farming under CAP Werner Kleinhanß, Carmen Murillo, Carlos San Juan y Stefan Sperlich 
272/2006 Riesgo asimétrico y estrategias de momentum en el mercado de valores español Luis Muga y Rafael Santamaría

273/2006 Valoración de capital-riesgo en proyectos de base tecnológica e innovadora a través de la teoría de opciones reales

Gracia Rubio Martín

274/2006 Capital stock and unemployment: searching for the missing link

Ana Rosa Martínez-Cañete, Elena Márquez de la Cruz, Alfonso Palacio-Vera and Inés PérezSoba Aguilar

275/2006 Study of the influence of the voters' political culture on vote decision through the simulation of a political competition problem in Spain

Sagrario Lantarón, Isabel Lillo, $\mathrm{M}^{\mathrm{a}}$ Dolores López and Javier Rodrigo

276/2006 Investment and growth in Europe during the Golden Age

Antonio Cubel and $\mathrm{M}^{\mathrm{a}}$ Teresa Sanchis

277/2006 Efectos de vincular la pensión pública a la inversión en cantidad y calidad de hijos en un modelo de equilibrio general

Robert Meneu Gaya

278/2006 El consumo y la valoración de activos

Elena Márquez y Belén Nieto

279/2006 Economic growth and currency crisis: A real exchange rate entropic approach

David Matesanz Gómez y Guillermo J. Ortega

280/2006 Three measures of returns to education: An illustration for the case of Spain

María Arrazola y José de Hevia

281/2006 Composition of Firms versus Composition of Jobs

Antoni Cunyat

282/2006 La vocación internacional de un holding tranviario belga: la Compagnie Mutuelle de Tramways, 1895-1918

Alberte Martínez López

283/2006 Una visión panorámica de las entidades de crédito en España en la última década.

Constantino García Ramos

284/2006 Foreign Capital and Business Strategies: a comparative analysis of urban transport in Madrid and Barcelona, 1871-1925

Alberte Martínez López

285/2006 Los intereses belgas en la red ferroviaria catalana, 1890-1936

Alberte Martínez López

286/2006 The Governance of Quality: The Case of the Agrifood Brand Names

Marta Fernández Barcala, Manuel González-Díaz y Emmanuel Raynaud

287/2006 Modelling the role of health status in the transition out of malthusian equilibrium

Paolo Rungo, Luis Currais and Berta Rivera

288/2006 Industrial Effects of Climate Change Policies through the EU Emissions Trading Scheme

Xavier Labandeira and Miguel Rodríguez 
289/2006 Globalisation and the Composition of Government Spending: An analysis for OECD countries Norman Gemmell, Richard Kneller and Ismael Sanz

290/2006 La producción de energía eléctrica en España: Análisis económico de la actividad tras la liberalización del Sector Eléctrico

Fernando Hernández Martínez

291/2006 Further considerations on the link between adjustment costs and the productivity of R\&D investment: evidence for Spain

Desiderio Romero-Jordán, José Félix Sanz-Sanz and Inmaculada Álvarez-Ayuso

292/2006 Una teoría sobre la contribución de la función de compras al rendimiento empresarial Javier González Benito

293/2006 Agility drivers, enablers and outcomes: empirical test of an integrated agile manufacturing model Daniel Vázquez-Bustelo, Lucía Avella and Esteban Fernández

294/2006 Testing the parametric vs the semiparametric generalized mixed effects models

María José Lombardía and Stefan Sperlich

295/2006 Nonlinear dynamics in energy futures

Mariano Matilla-García

296/2006 Estimating Spatial Models By Generalized Maximum Entropy Or How To Get Rid Of W

Esteban Fernández Vázquez, Matías Mayor Fernández and Jorge Rodriguez-Valez

297/2006 Optimización fiscal en las transmisiones lucrativas: análisis metodológico

Félix Domínguez Barrero

298/2006 La situación actual de la banca online en España

Francisco José Climent Diranzo y Alexandre Momparler Pechuán

299/2006 Estrategia competitiva y rendimiento del negocio: el papel mediador de la estrategia y las capacidades productivas

Javier González Benito y Isabel Suárez González

300/2006 A Parametric Model to Estimate Risk in a Fixed Income Portfolio

Pilar Abad and Sonia Benito

301/2007 Análisis Empírico de las Preferencias Sociales Respecto del Gasto en Obra Social de las Cajas de Ahorros

Alejandro Esteller-Moré, Jonathan Jorba Jiménez y Albert Solé-Ollé

302/2007 Assessing the enlargement and deepening of regional trading blocs: The European Union case Salvador Gil-Pareja, Rafael Llorca-Vivero y José Antonio Martínez-Serrano

303/2007 ¿ ¿Es la Franquicia un Medio de Financiación?: Evidencia para el Caso Español Vanesa Solís Rodríguez y Manuel González Díaz

304/2007 On the Finite-Sample Biases in Nonparametric Testing for Variance Constancy Paulo M.M. Rodrigues and Antonio Rubia

305/2007 Spain is Different: Relative Wages 1989-98

José Antonio Carrasco Gallego 
Poverty reduction and SAM multipliers: An evaluation of public policies in a regional framework Francisco Javier De Miguel-Vélez y Jesús Pérez-Mayo

307/2007 La Eficiencia en la Gestión del Riesgo de Crédito en las Cajas de Ahorro Marcelino Martínez Cabrera

308/2007 Optimal environmental policy in transport: unintended effects on consumers' generalized price M. Pilar Socorro and Ofelia Betancor

309/2007 Agricultural Productivity in the European Regions: Trends and Explanatory Factors Roberto Ezcurra, Belen Iráizoz, Pedro Pascual and Manuel Rapún

310/2007 Long-run Regional Population Divergence and Modern Economic Growth in Europe: a Case Study of Spain

María Isabel Ayuda, Fernando Collantes and Vicente Pinilla

311/2007 Financial Information effects on the measurement of Commercial Banks' Efficiency Borja Amor, María T. Tascón and José L. Fanjul

312/2007 Neutralidad e incentivos de las inversiones financieras en el nuevo IRPF Félix Domínguez Barrero

313/2007 The Effects of Corporate Social Responsibility Perceptions on The Valuation of Common Stock Waymond Rodgers , Helen Choy and Andres Guiral-Contreras

314/2007 Country Creditor Rights, Information Sharing and Commercial Banks’ Profitability Persistence across the world

Borja Amor, María T. Tascón and José L. Fanjul

315/2007 ¿ ¿Es Relevante el Déficit Corriente en una Unión Monetaria? El Caso Español Javier Blanco González y Ignacio del Rosal Fernández

316/2007 The Impact of Credit Rating Announcements on Spanish Corporate Fixed Income Performance: Returns, Yields and Liquidity

Pilar Abad, Antonio Díaz and M. Dolores Robles

317/2007 Indicadores de Lealtad al Establecimiento y Formato Comercial Basados en la Distribución del Presupuesto

Cesar Augusto Bustos Reyes y Óscar González Benito

318/2007 Migrants and Market Potential in Spain over The XXth Century: A Test Of The New Economic Geography

Daniel A. Tirado, Jordi Pons, Elisenda Paluzie and Javier Silvestre

319/2007 El Impacto del Coste de Oportunidad de la Actividad Emprendedora en la Intención de los Ciudadanos Europeos de Crear Empresas

Luis Miguel Zapico Aldeano

320/2007 Los belgas y los ferrocarriles de vía estrecha en España, 1887-1936

Alberte Martínez López

321/2007 Competición política bipartidista. Estudio geométrico del equilibrio en un caso ponderado Isabel Lillo, $\mathrm{M}^{\mathrm{a}}$ Dolores López y Javier Rodrigo

322/2007 Human resource management and environment management systems: an empirical study Mª Concepción López Fernández, Ana M Ma Serrano Bedia and Gema García Piqueres 
323/2007 Wood and industrialization. evidence and hypotheses from the case of Spain, 1860-1935. Iñaki Iriarte-Goñi and María Isabel Ayuda Bosque

324/2007 New evidence on long-run monetary neutrality.

J. Cunado, L.A. Gil-Alana and F. Perez de Gracia

325/2007 Monetary policy and structural changes in the volatility of us interest rates. Juncal Cuñado, Javier Gomez Biscarri and Fernando Perez de Gracia

326/2007 The productivity effects of intrafirm diffusion.

Lucio Fuentelsaz, Jaime Gómez and Sergio Palomas

327/2007 Unemployment duration, layoffs and competing risks.

J.M. Arranz, C. García-Serrano and L. Toharia

328/2007 El grado de cobertura del gasto público en España respecto a la UE-15

Nuria Rueda, Begoña Barruso, Carmen Calderón y $\mathrm{M}^{\mathrm{a}}$ del Mar Herrador

329/2007 The Impact of Direct Subsidies in Spain before and after the CAP'92 Reform

Carmen Murillo, Carlos San Juan and Stefan Sperlich

330/2007 Determinants of post-privatisation performance of Spanish divested firms

Laura Cabeza García and Silvia Gómez Ansón

331/2007 ¿Por qué deciden diversificar las empresas españolas? Razones oportunistas versus razones económicas

Almudena Martínez Campillo

332/2007 Dynamical Hierarchical Tree in Currency Markets

Juan Gabriel Brida, David Matesanz Gómez and Wiston Adrián Risso

333/2007 Los determinantes sociodemográficos del gasto sanitario. Análisis con microdatos individuales Ana María Angulo, Ramón Barberán, Pilar Egea y Jesús Mur

334/2007 Why do companies go private? The Spanish case

Inés Pérez-Soba Aguilar

335/2007 The use of gis to study transport for disabled people

Verónica Cañal Fernández

336/2007 The long run consequences of M\&A: An empirical application

Cristina Bernad, Lucio Fuentelsaz and Jaime Gómez

337/2007 Las clasificaciones de materias en economía: principios para el desarrollo de una nueva clasificación

Valentín Edo Hernández

338/2007 Reforming Taxes and Improving Health: A Revenue-Neutral Tax Reform to Eliminate Medical and Pharmaceutical VAT

Santiago Álvarez-García, Carlos Pestana Barros y Juan Prieto-Rodriguez

339/2007 Impacts of an iron and steel plant on residential property values

Celia Bilbao-Terol 